\title{
Immunoperoxidase staining of surface and intracellular immunoglobulin in human neoplastic lymphoid cells
}

\author{
DAVID Y MASON,* ROBERT CF LEONARD, $\dagger$ GUY LAURENT, $\ddagger$ AND \\ MARIE-FRANÇOISE GOURDIN $\ddagger$
}

From the *Department of Pathology, $\dagger$ Nuffield Department of Clinical Medicine, John Radcliffe Hospital, Oxford, UK and the $\ddagger$ Anaemia Research Unit (INSERM U91), Henri Mondor Hospital, Créteil, France

SUMMARY An immunoperoxidase technique for the optical microscopic detection of cellular immunoglobulin has been used to stain fixed smears of human neoplastic B lymphoid cells.

Only four out of 28 cases of chronic lymphatic leukaemia (CLL) showed membrane labelling by this technique. In contrast, when 14 samples from other types of B lymphoproliferative disorder (including hairy cell leukaemia, non-Hodgkin's lymphoma, and prolymphocytic leukaemia) were studied, all samples showed membrane immunoglobulin labelling (confirmed by capping experiments). This discrepancy was attributed to the greater density of surface immunoglobulin present on neoplastic cells in the latter group of disorders compared to CLL.

This immunoperoxidase technique is therefore less sensitive than immunofluorescent staining of cells in suspension for the demonstration of neoplastic cell surface immunoglobulin. However, it offers a number of advantages (eg, excellent visualisation of cell morphology, permanence of stained preparations, and applicability to stored samples) which recommend it as the method of choice in certain clinical haematological contexts.

In a previous paper it was reported that membrane immunoglobulin on the surface of normal human B cells may be revealed by applying an immunoperoxidase 'sandwich' to fixed smears of washed cells. ${ }^{1}$ This technique yields permanent preparations which, when examined by routine light microscopy, show a dense peripheral deposit of brown peroxidase reaction product around positive cells, which contrasts clearly with the haematoxylin counterstain. In addition to excellent cytological detail, this method offers the advantage that (since cells are smeared and fixed before exposure to antibody) surface membrane features (eg, villous processes) are preserved. Furthermore, the preliminary smearing and fixation of cells prevents non-specific membrane binding of antibody via its $\mathrm{Fc}$ region, ${ }^{2}$ a phenomenon that is an important cause of non-specific labelling in conventional immunofluorescent procedures. ${ }^{34}$

In the present paper we report our experience in the application of this immunoperoxidase procedure to the staining of neoplastic cell surface immuno-

Received for publication 10 December 1979 globulin in a variety of human B lymphoproliferative disorders.

\section{Patients and methods}

PATIENTS AND CELL SAMPLES

Samples of EDTA anticoagulated peripheral blood and bone marrow were obtained from patients attending the Radcliffe Infirmary, Oxford, the Henri Mondor Hospital, Créteil, and the St Louis Hospital, Paris. Spleen cells were obtained from two patients by dicing a portion of this organ obtained at splenectomy and separating mononuclear cells on a Triosil-Ficoll gradient. Cells were washed three times in isotonic phosphate buffered saline containing bovine serum albumin and EDTA ${ }^{5}$ and smeared on clean glass slides. When most peripheral blood samples were being studied the buffy coat was aspirated at the end of the first wash and the underlying red cells were discarded so as to increase the percentage of leucocytes in the cell smear. Smears were air dried and either stained on the day of preparation or wrapped in aluminium foil and 
stored at $-20^{\circ} \mathrm{C}$ for subsequent staining. This storage procedure had no detectable effect on the intensity of immunoperoxidase staining.

\section{REAGENTS}

Antisera and peroxidase: antiperoxidase (PAP) complexes were obtained from Dakopatts A/s. For surface immunoglobulin redistribution experiments cells were incubated with $\mathrm{F}\left(\mathrm{ab}^{\prime}\right)_{2}$ rabbit anti-IgM or anti- $\kappa$ antibodies which had been prepared in this laboratory. In one redistribution experiment (patient MF), a fluorescent anti- $\mu$ conjugate kindly provided by Dr J-L Preud'homme was used.

Diaminobenzidine tetrahydrochloride was obtained from Sigma Chemical Co Ltd.

\section{IMMUNOPEROXIDASE STAINING}

Blood, bone marrow, and spleen cell samples were prepared and stained for immunoglobulin heavy and light chains by the immunoperoxidase procedure as previously described. ${ }^{1}$ In summary, this involves fixation of cell smears for 30 seconds in buffered

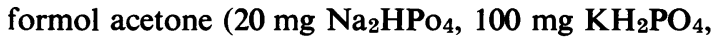
$45 \mathrm{ml}$ acetone, $25 \mathrm{ml}$ conc formalin, $30 \mathrm{ml}$ distilled water) before rinsing in distilled water and exposure to methanol containing $0.3 \% \mathrm{H}_{2} \mathrm{O}_{2}$ for 30 minutes (to block endogenous cellular peroxidase activity). Slides are then washed in $\mathrm{pH} 7.6$ Tris buffered saline (TBS) containing $0.15 \mathrm{M} \mathrm{NaCl}$ and $0.05 \mathrm{M}$ Tris- $\mathrm{HCl}$ before exposure to the following sequence of reagents:

1 Rabbit anti-human $\gamma, \mu \kappa$ or $\lambda$ chains (1/50$1 / 200,30 \mathrm{~min}$ )

2 Swine anti-rabbit $\operatorname{IgG}(1 / 25,30 \mathrm{~min})$

3 Rabbit antiperoxidase: peroxidase (PAP) complexes $(1 / 100,30 \mathrm{~min})$

4 Diaminobenzidine tetrahydrochloride $(0.6 \mathrm{mg}$ / $\mathrm{ml}$ ) plus $0.01 \% \mathrm{H}_{2} \mathrm{O}_{2}(5-10 \mathrm{~min})$.

Each reagent is diluted in TBS, and slides are washed in TBS after each incubation step. After the diaminobenzidine $/ \mathrm{H}_{2} \mathrm{O}_{2}$ step the slides are counterstained with haematoxylin and mounted in DPX.

Controls were provided by comparing the staining results obtained for different immunoglobulin chains $(\gamma, \mu, \kappa, \lambda)$ and omitting the primary anti-Ig antiserum.

\section{ANTIBODY-INDUCED REDISTRIBUTION}

('CAPPING') OF MEMBRANE IMMUNOGLOBULIN Triosil-Ficoll separated peripheral lymphoid cell suspensions were washed in Hank's solution containing $5 \%$ bovine serum albumin (Hank's BSA) and incubated in aliquots of $2-4 \times 10^{6}$ cells at $0^{\circ} \mathrm{C}$ with $\mathrm{F}\left(\mathrm{ab}^{\prime}\right)_{2}$ rabbit anti-IgM or anti- $\kappa$ antibodies, diluted in $0.1 \mathrm{ml}$ of Hank's BSA. After 30 minutes cells were washed in cold Hank's BSA, resuspended in this medium, incubated for a further 30 minutes at $37^{\circ} \mathrm{C}$, and finally washed three times in Hank's BSA before being smeared on glass slides. Smears were then stained by the PAP procedure as outlined above.

Details of neoplastic B lymphoid cell samples giving positive reaction for membrane immunoglobulin when stained as cell smears by the PAP technique

\begin{tabular}{|c|c|c|c|c|c|c|c|c|}
\hline \multirow[t]{2}{*}{ Patient } & \multirow[t]{2}{*}{ Diagnosis } & \multirow[t]{2}{*}{ Cell sample } & \multicolumn{5}{|c|}{ Immunoperoxidase reaction || } & \multirow[t]{2}{*}{ Membrane Ig type } \\
\hline & & & $\operatorname{Ig} M$ & $\operatorname{Ig} G$ & $\operatorname{Ig} A$ & $\kappa$ & $\lambda$ & \\
\hline FL & Hairy cell leukaemia & Peripheral blood & \pm & - & NT & + & - & $(\mathbf{I g M}) \kappa \ddagger$ \\
\hline $\mathbf{J} \mathbf{M}$ & Hairy cell leukaemia & Peripheral blood & + & + & NT & - & + & $\operatorname{IgM}, \operatorname{IgG} \lambda$ \\
\hline $\mathbf{C M}$ & Hairy cell leukaemia & Peripheral blood & + & + & NT & + & \pm & $\operatorname{IgM}, \operatorname{IgG} \kappa(\lambda)$ \\
\hline FP & Hairy cell leukaemia & Peripheral blood & + & - & NT & NT & NT & IgM \\
\hline EP & Lymphocytic lymphoma & Peripheral blood & + & - & NT & - & + & $\operatorname{IgM} \lambda \ddagger$ \\
\hline HP & Lymphocytic lymphoma & Peripheral blood & + & - & NT & - & + & $\operatorname{IgM} \lambda \ddagger$ \\
\hline TW & Centrocytic lymphoma & $\begin{array}{l}\text { Peripheral blood } \\
\text { and spleen cells }\end{array}$ & + & - & NT & + & - & IgM $\kappa_{\ddagger}^{+}$ \\
\hline TS & Centrocytic lymphoma & Peripheral blood & + & NT & NT & + & - & $\operatorname{IgM} \kappa$ \\
\hline BH & Centrocytic lymphoma & Peripheral blood & + & NT & NT & - & + & $\mathbf{I g M} \lambda$ \\
\hline CD & Centroblastic lymphoma & Peripheral blood & + & + & NT & + & - & IgM, IgG $\kappa$ \\
\hline Ww & Prolymphocytic leukaemia & Peripheral blood & + & - & NT & + & - & IgM $\kappa \ddagger$ \\
\hline NC & Prolymphocytıc leukaemia & $\begin{array}{l}\text { Peripheral blood } \\
\text { and spleen cells }\end{array}$ & + & - & NT & + & - & IgMк \\
\hline FG & Prolymphocytic leukaemia & $\begin{array}{l}\text { Peripheral blood } \\
\text { and spleen cells }\end{array}$ & + & + & NT & + & - & $\operatorname{IgM}, \operatorname{IgG} \kappa \S$ \\
\hline MF & B cell acute lymphoblastic leukaemia & Bone marrow & + & NT & NT & NT & NT & IgM $\ddagger$ \\
\hline BV & Chronic lymphatic leukaemia* & Peripheral blood & - & - & + & - & + & $\operatorname{IgA} \lambda$ \\
\hline AS & Chronic lymphatic leukaemia $\dagger$ & Peripheral blood & - & + & NT & + & - & IgG $\kappa$ \\
\hline JB & Chronic lymphatic leukaemia & Peripheral blood & - & + & NT & + & - & $\operatorname{IgG} \kappa$ \\
\hline
\end{tabular}

*IgA $\lambda$ serum paraprotein; $+I g G \kappa$ serum paraprotein; $N T=$ not tested.

$\ddagger / \S$ : Location of Ig on surface of cells confirmed by capping ( $\ddagger)$ or by trypsinisation and resynthesis (§)—see Methods.

I|Scoring: +, majority of cells clearly stained.

-, majority of cells negative.

\pm , weak or equivocal staining. 


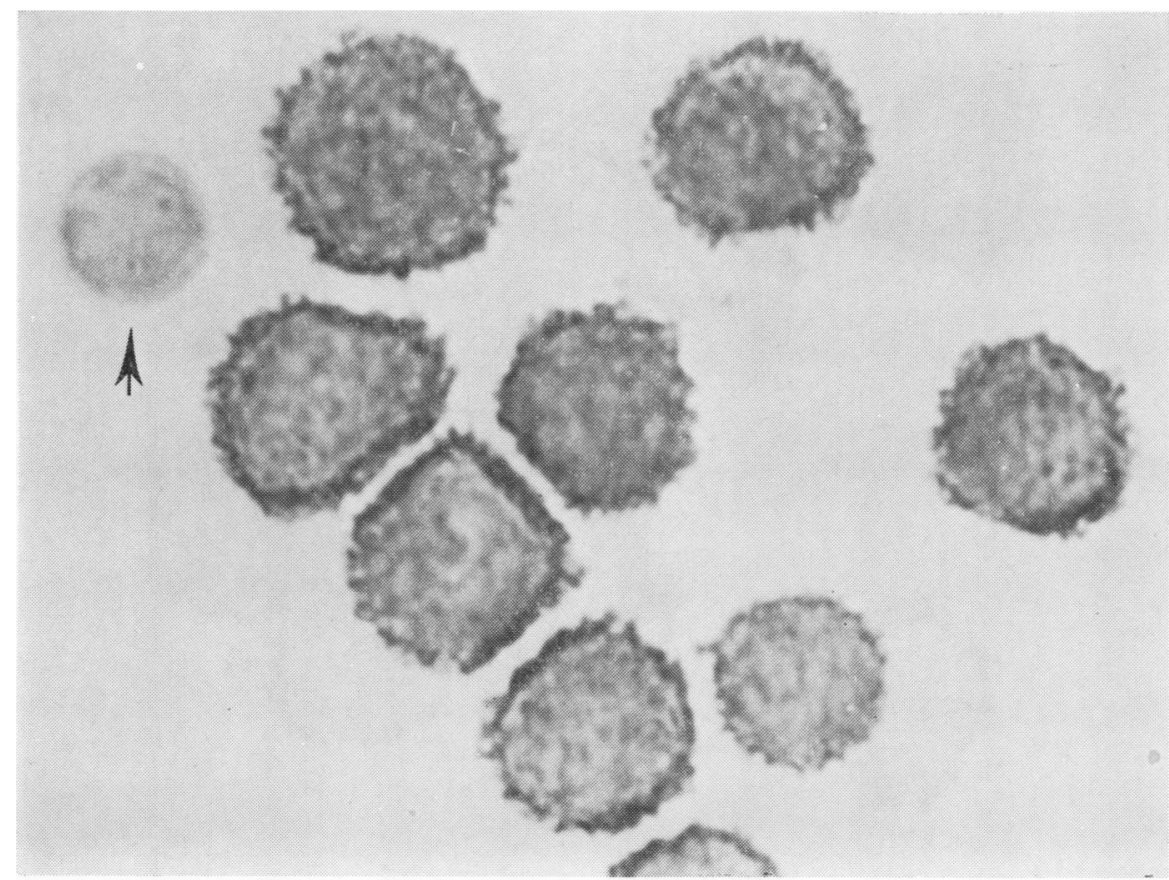

(a)

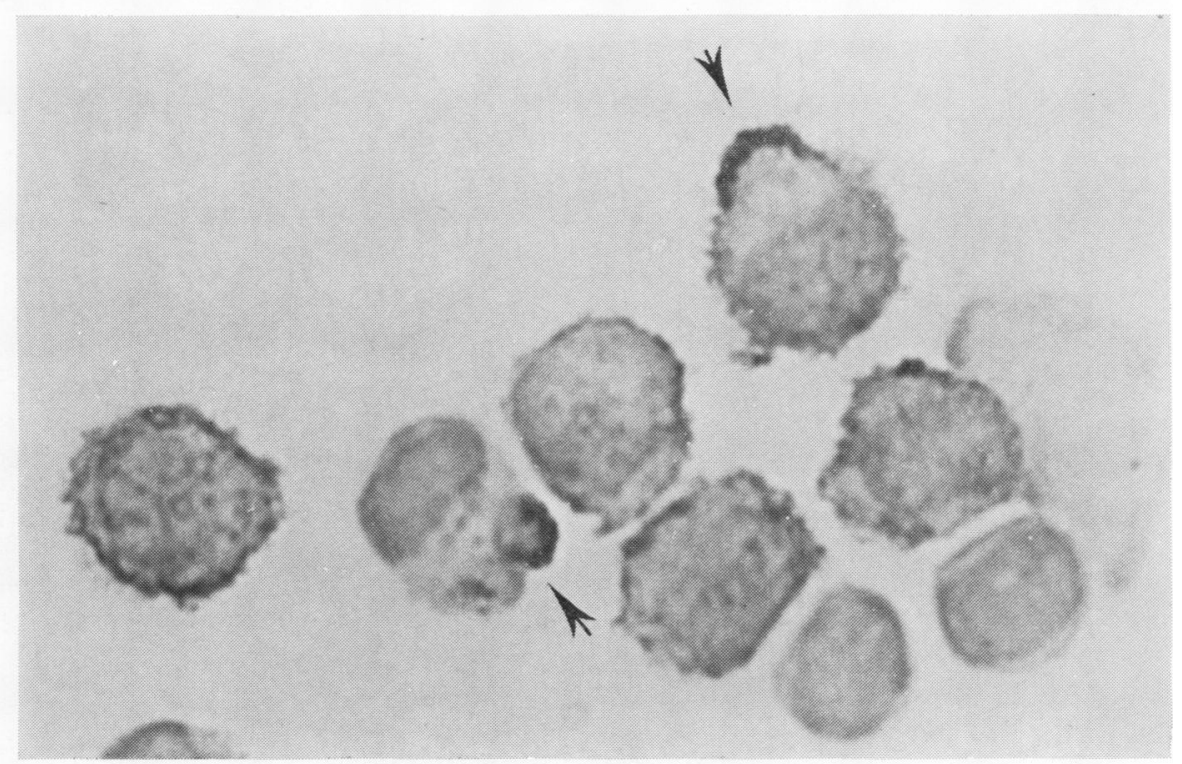

(b)

Fig. 1 (a) Peripheral blood from a case of hairy cell leukaemia (patient FL) stained for $\kappa$ chains. Note villous aspect of positive cells. A negative small lymphocyte is arrowed. $\times 3000$. (b) Cells from the same patient stained for $\kappa$ chains after incubation with $F\left(a b^{\prime}\right)_{2}$ anti- $\kappa$ antibody. Membrane staining is much weaker than in Fig. Ia, and positively stained caps are visible on some cells (arrowed). $\times 3000$. 


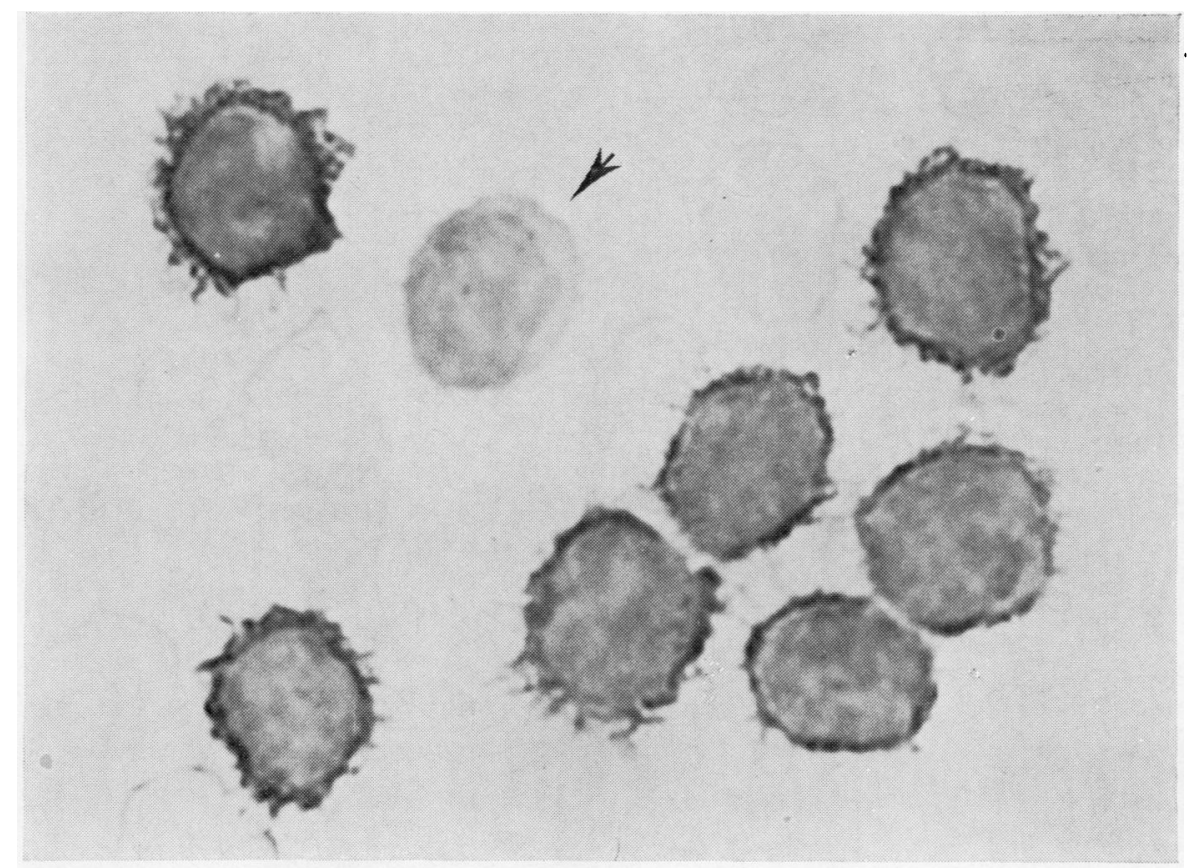

(a)

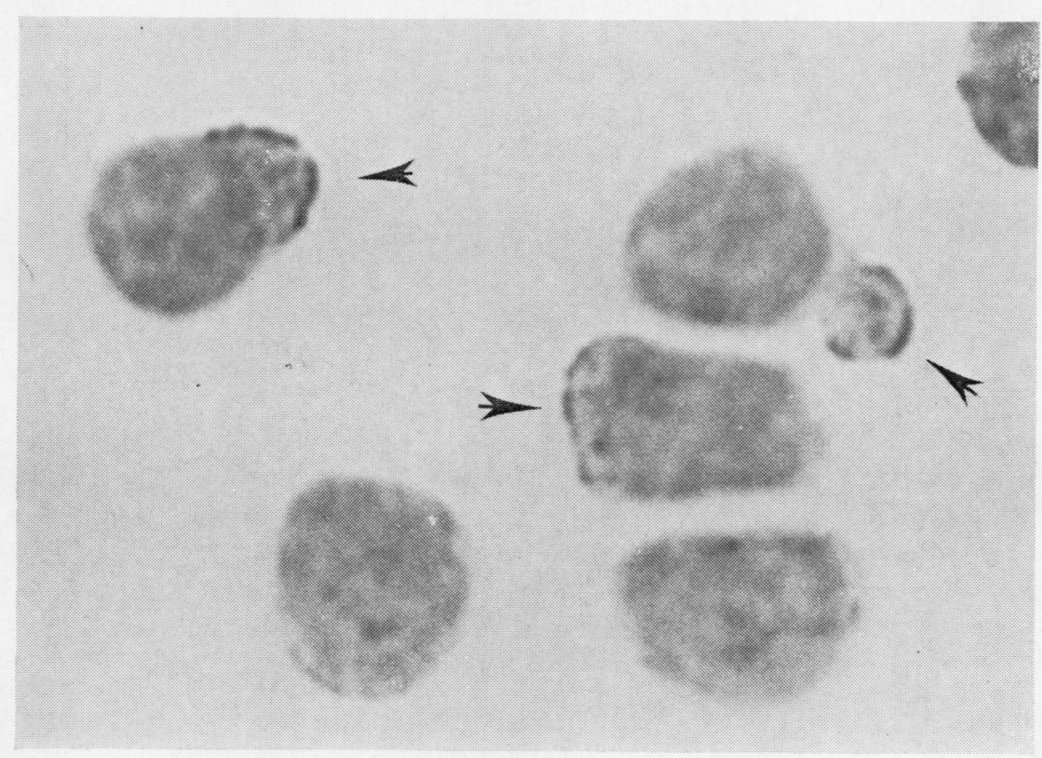

(b)

Fig. 2 (a) Bone marrow sample from a case of prolymphocytic leukaemia (patient NC) stained for IgM. A negative small lymphocyte is arrowed. $\times 2600$. (b) Cells from the same patient stained for IgM after incubation with $F\left(a b^{\prime}\right)_{2}$ anti-IgM. Note abolition of membrane staining and appearance of patchily stained caps (arrowed). $\times 2600$. 


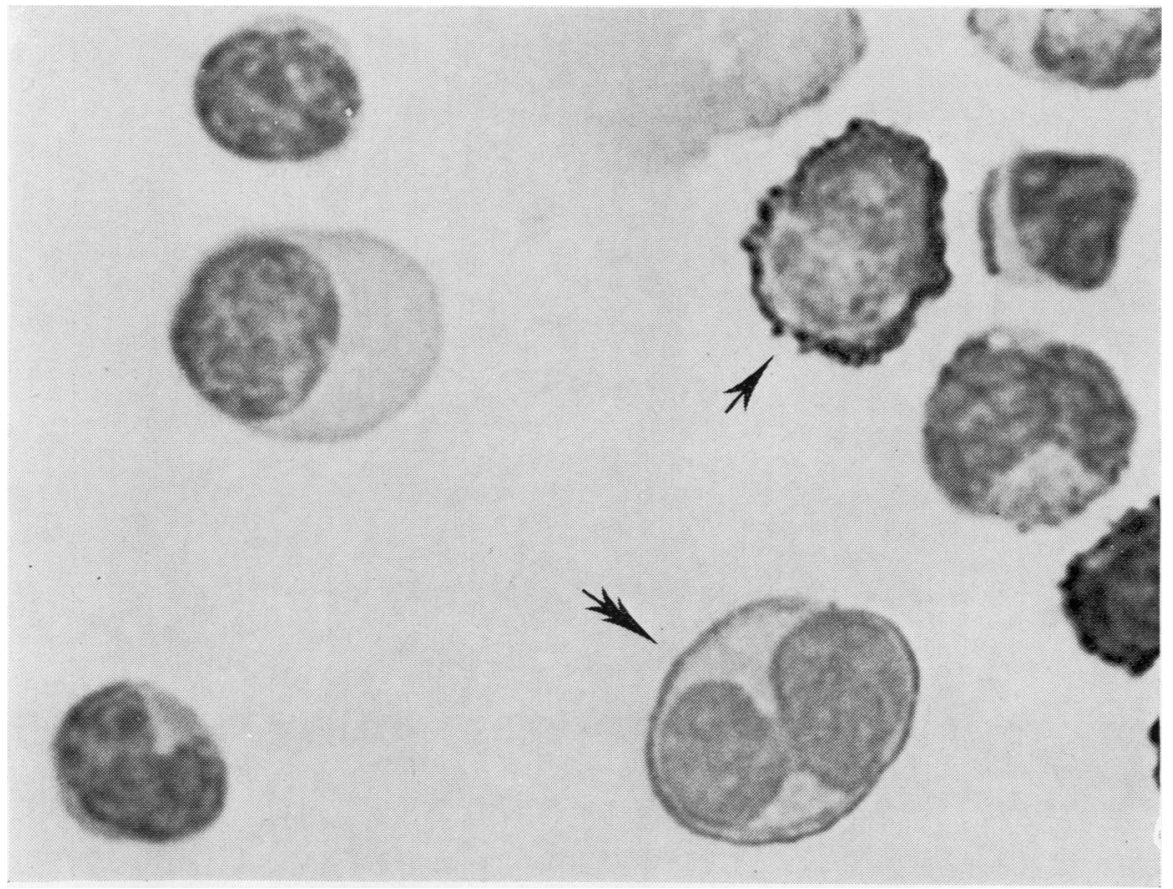

Fig. 3 Peripheral blood sample from a case of centrocytic lymphoma (patient TW) stained for IgM. A strongly positive cell (single arrow) showing villous membrane staining is seen together with a second more weakly stained cell (double arrow) with a smooth membrane profile. Note the 'wire ring' effect imparted by membrane staining in this cell and the clearly visualised cleft nuclear outline. $\times 2000$.

ENZYMATIC REMOVAL AND RESYNTHESIS OF MEMBRANE IMMUNOGLOBULIN

Cells were incubated in Hank's solution containing $0.2 \mathrm{mg} / \mathrm{ml}$ trypsin (Worthington Biochemical Corp) for 30 minutes at $37^{\circ} \mathrm{C}$. They were then washed and cultured in RPMI medium containing $10 \%$ fetal calf serum at $37^{\circ} \mathrm{C}$ in $5 \% \mathrm{CO}_{2}$ for 6 hours. Cell smears prepared after trypsinisation and after culture were stained by the PAP procedure.

\section{Results}

A total of 42 patients suffering from a variety of lymphoproliferative disorders were studied. Details of the positive staining reactions obtained by the immunoperoxidase technique are given in the Table.

\section{NON-CLL CASES}

In each of 14 cases of non-CLL lymphoproliferative disease (hairy cell leukaemia, non-Hodgkin's lymphoma, prolymphocytic leukaemia, B cell acute lymphoblastic leukaemia), positive immunoperoxidase staining for immunoglobulin of the majority of neoplastic cells was detected (Table). This immuno- globulin was considered to be localised to the surface membrane (see below), and in all but one case (in which an equivocal reaction was obtained) $\mu$ chains were detected. Staining for light chains was limited to a single class (with the exception of one case of hairy cell leukaemia in which strong staining for $\kappa$ chains was accompanied by equivocal staining for $\lambda$ chains).

The appearance of the immunoperoxidase reaction in these cases resembled the pattern previously described for IgM on normal human peripheral B cells. ${ }^{1}$ This characteristically took the form of diffuse weak labelling over the entire cell area (including both cytoplasm and nucleus) associated with a more intense staining of the cell margin, where a villous surface outline was frequently delineated (Figs 1a, 2a). However, not all neoplastic lymphoid cells showed this pattern; Fig. 3 illustrates a labelled cell from a case of centrocytic lymphoma which was unusually smooth in outline.

In all the samples studied in this investigation, cellular morphological detail was very easily visualised owing to the good preservation of cell structure by the formalin-containing fixative and the 


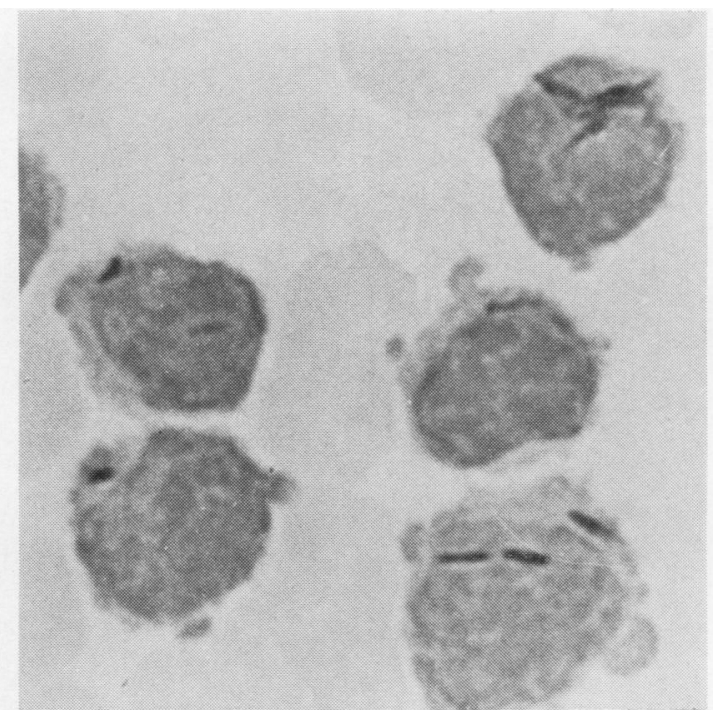

Fig. 4 (a) Peripheral blood from a case of chronic lymphatic leukaemia (patient $B C)$ stained for IgM.

Positively staining intracytoplasmic inclusions are visible in five of the lymphoid cells. $\times 3000$.

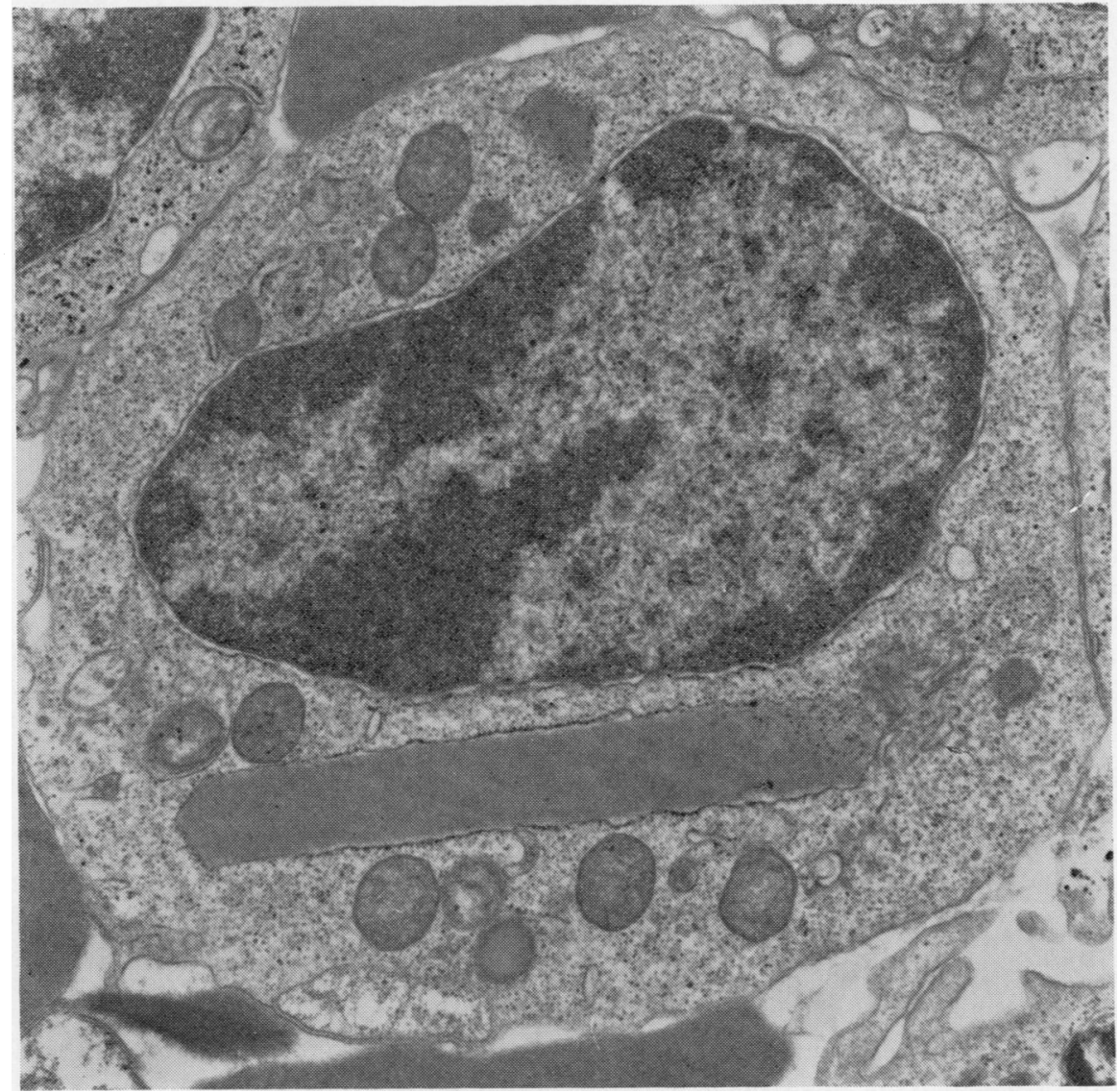

(b) Electron microscopic section of a lymphoid cell from the same case showing a crystalline inclusion corresponding to the immunoglobulin positive structures seen on immunoperoxidase staining of cell smears. $\times 20000$. 
crisp delineation of nuclear detail by the haematoxylin counterstain. A variety of alternative fixatives and counterstains were assessed during the course of this study but none provided better preservation of cellular detail.

Although the appearance of the immunoperoxidase staining reaction in the majority of cases suggested that immunoglobulin on the cell surface (rather than within the cytoplasm) was being detected, there were two cases in which the staining pattern was not so obviously localised to the membrane. However, in one of these cases (MF) exposure of cells in suspension to anti- $\mu$ antiserum before smearing and staining caused the labelling pattern to be replaced by small localised clumps of staining, while in the other (FG) the surface localisation of the immunoglobulin was inferred from its abolition by exposure of the cells in suspension to trypsin and its reappearance after short-term in vitro culture.

'Capping' experiments with anti- $\mu$ or anti- $\kappa$ antiserum to confirm the surface membrane localisation of the immunoglobulin detected by the immunoperoxidase technique were also performed in six other cases, in all of which clear redistribution of the label was observed (Figs 1b, 2b).

\section{CHRONIC LYMPHATIC LEUKAEMIA}

Samples from 28 CLL patients were studied. In three cases a membrane-labelling pattern (see above) was observed (Table). In two of these cases (BV, AS) a monoclonal serum paraprotein was present (of the same heavy and light chain type as the membrane immunoglobulin).

Cells from two other CLL patients (which were negative for surface immunoglobulin) contained fine rod-shaped inclusions (Fig. 4a) of immunoglobulin $(1 \operatorname{IgM} \kappa, 1 \operatorname{IgM} \lambda)$ which, on electron microscopic examination (Fig. 4b), showed the characteristic striated appearance previously described by other authors. ${ }^{6}$

None of the other 23 CLL samples gave clearly positive reactions with any of the anti-Ig antisera.

\section{Discussion}

This study demonstrates that surface immunoglobulin on a variety of human neoplastic lymphoid cells, including 'hairy' cells, B lymphoblasts, lymphoma cells, and prolymphocytes, can be visualised by optical microscopy after immunoperoxidase staining of cell smears. The cell surface (rather than intracytoplasmic) localisation of the immunoglobulin demonstrated in this study was inferred from the characteristic peripheral staining pattern, often delineating a villous cell margin, together with the redistribution of staining induced by preliminary exposure of cells to anti-immunoglobulin antibody before smearing.

The fact that surface immunoglobulin on neoplastic human lymphoid cells can be visualised by staining cell smears has not previously been reported. Zidar et al. ${ }^{7}$ have claimed that cytoplasmic immunoglobulin can be demonstrated within leukaemic hairy cells by immunocytochemical staining of cell smears. However, these authors appear not to have considered the possibility that they were demonstrating the dense surface coat of immunoglobulin carried by hairy cells. Both the method of fixation (methanol) and the staining technique (immunofluorescence) would have made it difficult to distinguish surface from cytoplasmic labelling. Immunoperoxidase staining of optimally fixed cell smears, as described above, would have given a clearer idea of the true location of immunoglobulin in these cells, although, even using this technique, it may be necessary to perform capping or trypsinisation techniques (see above) to detect cytoplasmic immunoglobulin within cells which carry large amounts of this material on their surface membrane.

In contrast to the strong labelling of immunoglobulin on cells such as prolymphocytes and B lymphoblasts, most CLL samples gave negative reactions, probably reflecting the lower density of surface immunoglobulin on CLL cells. ${ }^{8-11}$ Although its limited sensitivity restricts the value of PAP staining of cell smears as a general technique for surface antigen detection the technique possesses several advantages which may recommend it in specific haematological contexts. Principal among these is the excellent morphological detail visible in immunoperoxidase stained preparations (approaching that of a routine Romanovsky stained smear) which greatly aids the correct classification of positive cells. This is particularly of use when attempting to identify a minor population of neoplastic cells among a majority of normal cells, for example, in a bone marrow sample. It may be pointed out that the diagnosis and classification of many lymphoproliferative disorders rests upon the haematologist's ability to assess fine details of nuclear and cytoplasmic morphology. The exercise of this skill requires cell preparations that have been optimally fixed and stained. Clearly, immunocytochemical techniques (such as the procedure described above), which preserve cell morphology and allow it to be visualised simultaneously with a label for membrane antigens, offer major advantages to the haematologist. It may be possible in the future to combine a high level of sensitivity with the cytological advantages of immunoperoxidase labelling by incubating cells in suspension with unlabelled antiserum and then washing, smearing, and fixing them 
before applying the PAP sandwich. This approach avoids the denaturation of surface antigens caused by cell smearing (as may occur in the procedure used in the present paper) and has given good results in this laboratory when applied to the study of human cell surface antigens detected by murine monoclonal antibodies. ${ }^{12} 13$

In addition to the benefits of optimal cell visualisation, the PAP procedure offers a number of minor advantages such as the fact that cell smears can be stored frozen for prolonged periods before staining and that peroxidase stained preparations can be kept indefinitely without fading. Furthermore, immunoperoxidase staining can be performed on routine EDTA haematological samples (rather than on defibrinated blood), and relatively small numbers of lymphoid cells (a few hundred) are sufficient for staining. It may also be noted that the technique allows internal and membrane immunoglobulin to be simultaneously demonstrated, as illustrated by the two cases of CLL in which intracellular Ig crystals were stained. The authors of a large survey (72 patients) of these inclusions in CLL cells noted that artefacts (eg, small cytoplasmic folds) cause difficulties in the interpretation of immunofluorescent staining. ${ }^{14}$ Because of the greater cell detail visible, this is not a problem with the immunoperoxidase technique, which appears to be the method of choice for the study of these accumulations of immunoglobulin. 6915

We acknowledge the expert technical assistance of RE Sammons.

This investigation was supported by the Leukaemia Research Fund.

\section{References}

${ }^{1}$ Mason DY, Labaume S, Preud'homme JL. The detection of membrane and cytoplasmic immunoglobulins in human leucocytes by immunoperoxidase staining. Clin Exp Immunol 1977;29:413-21.

2 McKeever PE, Garvin AJ, Spicer SS. Immune complex receptors on cell surfaces I. Ultrastructural demonstration on macrophages. J Histochem Cytochem 1976; 24:948-55.
${ }^{3}$ Preud'homme JL, Labaume S. Detection of surface immunoglobulin on human cells by direct immunofluorescence. In: Bloom BR, David JR, eds. In vitro Methods in Cell-mediated Immunity. New York: Academic Press, 1976;145-58.

${ }^{4}$ Winchester RJ. Techniques of surface immunofluorescence applied to the analysis of the lymphocyte. In: Bloom BR, David JR, eds. In vitro Methods in Cell-mediated Immunity. New York: Academic Press, 1976;171-82.

${ }^{5}$ Hijmans W, Schuit HRE, Klein F. An immunofluorescence procedure for the detection of intracellular immunoglobulins. Clin Exp Immunol 1969;4:457-72.

- Hurez D, Flandrin, G, Preud'homme JL, Seligmann M. Unreleased intracellular monoclonal macroglobulin in chronic lymphocytic leukaemia. Clin Exp Immunol 1972;10:223-34.

${ }^{7}$ Zidar BL, Winkelstein A, Whiteside TL et al. Hairy cell leukaemia: seven cases with probably B-lymphocytic origin. Brit J Haematol 1977;37:455-65.

${ }^{8}$ Cooper AG, Brown MC, Derby HA, Wortis HH. Quantitation of surface-membrane and intracellular gamma, mu and kappa chains of normal and neoplastic human lymphocytes. Clin Exp Immunol 1973;13:487-96.

- Preud'homme JL, Seligmann M. Surface immunoglobulins on human lymphoid cells. Prog Clin Immunol 1974; 2:121-74.

${ }^{10}$ Aisenberg AC, Wilkes B. Lymphosarcoma cell leukemia: the contribution of cell surface study to diagnosis. Blood 1976;48:707-15.

${ }^{11}$ Dighiero G, Follezou JY, Roison JP, Ternynck T, Binet JL. Comparison of normal and chronic lymphocytic leukaemia lymphocyte surface IgG determinants using peroxidase labeled antibodies. II. Quantification of light chains determinants in atypical lymphocytic leukemia. Blood 1976;48:559-66.

12 Brown, G, Biberfeld P, Christensson B, Mason DY. The distribution of HLA on human lymphoid, bone marrow and peripheral blood cells. Eur J Immunol 1979;9:272-5.

13 McMichael AJ, Pilch JR, Galfré G, Mason DY, Fabre JW, Milstein C. A human thymocyte antigen defined by a hybrid myeloma monoclonal antibody. Eur J Immunol 1979;9:205-10.

${ }^{14}$ Cawley JC, Smith J, Goldstone AH, Emmines J, Hamblin $\mathrm{J}$, Hough $\mathrm{L}$. IgA and IgM cytoplasmic inclusions in a series of cases of chronic lymphocytic leukaemia. Clin Exp Immunol 1976;23:78-82.

15 Clark C, Rydell RE, Kaplan ME. Frequent association of $\operatorname{IgM} \lambda$ with crystalline inclusions in chronic lymphatic leukemic lymphocytes. $N$ Engl J Med 1973;289:113-7.

Requests for reprints to: Dr DY Mason, Haematology Department, John Radcliffe Hospital, Oxford OX3 9DU, UK. 